\title{
Obituaries
}

Obituaries should be submitted by email to Kate Maynard at k.maynard@nature.com.

All submitted obituaries should be 350 words maximum in length (apart from obituaries for past presidents of the BDA where the length should be $700-800$ words).

Content of the obituary is down to the individual author, and the approval of the family should be given for the obituary prior

to submission to the $B D J$.

\section{GEORGE SHERWOOD HOBSON}

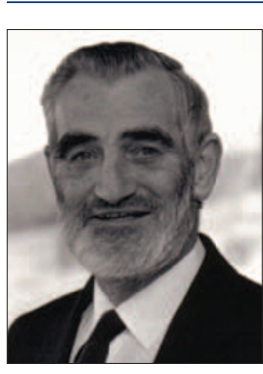

Hobson, known and colleagues, a short illness in hospital on 4
George Sherwood

as Sherwood to

his many friends passed away after November 2011.

Born in Belfast in 1930, Sherwood attended Wallace High School and Methodist College, excelling both academically and on the sports field, before going to Queen's University where he gained his BDS in 1953. Married to Muriel in 1957 theirs was a formidable, loving partnership, each encouraging the other in their endeavours and those of their family, Ross, Leigh and Barry.

After qualifying Sherwood worked in general dentistry in the Downshire Hospital and in the School of Dentistry Belfast, where he developed an interest in orthodontics. Sherwood set up the first solely orthodontic practice in Northern Ireland in 1959, and continued with his teaching appointment sharing his practical approach and enthusiasm with those in the Orthodontic Department. He attended both British and European Orthodontic Society meetings to become familiar with the Begg techniques which he then used to create the 'Hobson smile'. Various local dental committees and the BDA benefited from his insight and input, and the profession is indebted to him for his negotiating skills. In 1976 Sherwood was Northern Ireland Branch President of the BDA. In 1981 he was elected Fellow of the International College of Dentistry and after retiring from practice in 2000 he was honoured with BDA life membership.
Outside dentistry, Sherwood played an active and prominent role for many years with Larne Golf Club. He was a member of Malone Golf Club and the University Golfing Society. This interest in golf helped fill a little of the tremendous gap left by Muriel's death in 2007.

Local dramatic societies involved Sherwood as a director or producer. He travelled throughout the province in the 1970s and 1980s and could recount many amusing stories of being stopped at police and army checkpoints in a car filled with disguises, props and wiring.

Sherwood enjoyed life and helping wherever he could. He will be missed by his many friends and colleagues. To his family we offer our sincere condolences.

D. McLeod, R. Hobson

\section{ANDREW CARMICHAEL}

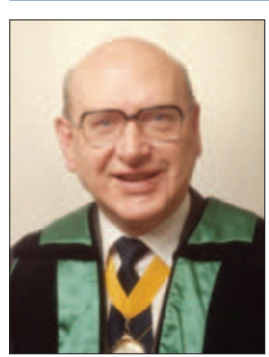

Andrew Carmichael was one of Scotland's leading dental surgeons and teachers who specialised in the care of children. Born in Falkirk in 1926, he attended

Allan Glen's School in Glasgow before studying dentistry, qualifying LDS in 1949. In 1950 Andrew married his wife, Rena, a fellow dental student, prior to being called up for National Service, serving as a Captain in the Royal Army Dental Corps in Italy.

The family returned to Scotland in 1951. Andrew joined a dental practice in Parkhead but within a year he was appointed lecturer in conservative dentistry at Glasgow University. Within a short time he was in charge of the children's department at the Dental Hospital and School, developing preventive dentistry as well as restorative care. His calm, gentle and patient manner helped him excel in the care of children with special needs. He recognised the vital role played by dental nurses and introduced formal training for them. He also developed health promotion campaigns such as the very successful Happy Smile Club of the 1960s.

During his distinguished career, he was President of the Paedodontic Society, Convenor of the Dental Council, Royal College of Physicians and Surgeons of Glasgow, member of the Specialist Advisory Committee for Community Dental Health and a member of the General Dental Council. As a committee member, his wise counsel and dry sense of humour were much appreciated.

In retirement, he was President of the Kelvin Probus Club, a keen and creative gardener and he learned to play the accordion. In his youth a piper in the Boys Brigade Pipe Band, he would often boast that he had played in a ScotlandEngland football match at Hampden Park, only to reveal that it was during the interval in the massed pipe band!

Andrew Carmichael will be fondly remembered by generations of Glasgow dental students as a gifted teacher and dental surgeon who influenced the professional development of many younger colleagues and contributed so much to the welfare of his patients and our profession.

He is survived by his wife of 61 years, Rena, his three children, Kathleen, Iain and Gordon, and six grandchildren.

DKM 